\title{
Somatostatin Effects on Cultured Human Fetal Epiphyseal Chondrocytes
}

\author{
M. A. FERRÁNDEZ, A. CARRASCOSA, L. AUdí, AND A. BALLABRIGA \\ Department of Pediatrics and Biomedical Research Unit, Hospital Universitario Materno-Infantil Vall d'Hebron, \\ Autonomous University, Barcelona, Spain
}

\begin{abstract}
Somatostatin effects on cultured human fetal epiphyseal chondrocytes were evaluated by studying the effects of somatostatin on DNA synthesis. Cultured epiphyseal chondrocytes from human fetuses (12-40 wk old) were incubated for $48 \mathrm{~h}$ in Ham's F-12 serum-free medium. After this, the medium was replaced by MCDB-104 serumfree medium and the cells were incubated for an additional $48 \mathrm{~h}$ in the presence or absence of somatostatin $1 \mathrm{pM}$ to $10 \mu \mathrm{M}$, with the addition of ${ }^{3} \mathrm{H}$-thymidine $(5 \mu \mathrm{Ci} / \mathrm{mL})$ for the last $24 \mathrm{~h}$ of incubation. A significant $(p<0.02)$ inhibitory effect of somatostatin $(1 \mathrm{nM}$ to $10 \mu \mathrm{M})$ on ${ }^{3} \mathrm{H}$ thymidine DNA incorporation was observed in cultured chondrocytes from fetuses of all gestational ages studied (12-40 wk), with no significant differences among fetal ages. In conclusion, our results show that somatostatin exerts a biologic effect on cultured human fetal epiphyseal chondrocytes, as it does in its target cells. These results suggest that somatostatin could regulate human skeletal growth not only by growth hormone secretion regulation, but also by acting directly on chondrocyte metabolism. However, the physiologic significance of the latter remains to be elucidated. (Pediatr Res 32: 571-573, 1992)
\end{abstract}

Longitudinal bone growth results from the proliferation and differentiation of chondrocytes in epiphyseal cartilage (1). Hypothalamic somatostatin influences this process through growth hormone secretion regulation $(2,3)$. However, somatostatin is also secreted by other extrahypothalamic tissues $(4,5)$.

In humans, somatostatin has been found in hypothalamic tissue during fetal development (6), and in vitro studies have shown that human placental tissue is able to synthesize somatostatin $(7,8)$, although the biologic significance of this fact remains to be clarified.

Cultured human fetal epiphyseal chondrocytes are a suitable in vitro model for the study of hormone effects on cartilage growth and differentiation (9-11).

The aims of the present work were to ascertain whether somatostatin exerts biologic effects on cultured human fetal epiphyseal chondrocytes. Thus, the effects of somatostatin on ${ }^{3} \mathrm{H}$-thymidine incorporation into DNA were evaluated in cultured chondrocytes from human fetuses $12-40 \mathrm{wk}$ old.

\section{MATERIALS AND METHODS}

Materials. Plastic $75-\mathrm{cm}^{2}$ tissue culture flasks were from Corning Glass (Corning, NY). Ninety-six-microwell tissue culture plates were purchased from Nunc (Copenhagen, Denmark)

Received February 3, 1992; accepted June 18, 1992.

Correspondence and reprint requests: Dr. Antonio Carrascosa, Jefe de Servicio de Pediatria, Hospital Materno-Infantil Vall d' Hebron, Paseo del Valle Hebron s/ n, 08035 Barcelona, Spain.
Trypsin was from Difco Laboratories, Inc. (Detroit, MI). Collagenase was from Worthington Biochemical Corp. (Freehold, NJ). FCS and culture media were from GIBCO (Grand Island, NY). Human placental cord serum was obtained from human umbilical cord blood at delivery; a simple pool was made and used throughout the study. ${ }^{3} \mathrm{H}$-thymidine (sp act, $22 \mathrm{Ci} / \mathrm{mmol}$ ) was purchased from Amersham (Radiochemical Centre, Amersham, UK). Glass fiber filters were purchased from Whittaker (Walkersville, MD). Unisolve scintillation fluid was obtained from Koch Light Lab (Colnbrook Berks, UK) and Triton X-100 from Sigma Chemical Co. (St. Louis, MO). Synthetic cyclic somatostatin was a gift from Serono Laboratories.

Chondrocyte culture. With informed parental consent, femoral epiphyseal cartilage was obtained from human fetuses and collected within $12 \mathrm{~h}$ postmortem. Chondrocytes were released by enzymatic digestion and cultured as previously described (12). Briefly, after enzymatic digestion with trypsin and collagenase, a chondrocyte suspension was obtained. Approximately 500000 cells were plated in a $75-\mathrm{cm}^{2}$ plastic culture flask with $12 \mathrm{~mL}$ of Ham's F-12 medium. The culture media were supplemented with $8 \%$ human placental cord serum, $4 \%$ FCS and $25 \mathrm{IU} / \mathrm{mL}$ penicillin. The flasks were maintained at $37^{\circ} \mathrm{C}$ in an atmosphere of $5 \% \mathrm{CO}_{2}$ in humid air. The cultures were fed by changing the medium every $2 \mathrm{~d}$.

DNA synthesis studies. These studies were carried out as previously described $(10,11)$. Primary confluent chondrocytes were trypsinized and plated in 96-microwell tissue culture plates at a density of 70000 cells/well in $0.3 \mathrm{~mL}$ Ham's F-12 serum and antibiotic-free medium. After $48 \mathrm{~h}$, this medium was aspirated and chondrocytes were incubated for an additional period of $48 \mathrm{~h}$ in MCDB-104 serum and antibiotic-free medium in the presence or absence of somatostatin $(10 \mathrm{pM}$ to $10 \mu \mathrm{M}) .{ }^{3} \mathrm{H}$ thymidine $(5 \mu \mathrm{Ci} / \mathrm{mL})$ was added for the last $24 \mathrm{~h}$ of incubation. Five different wells were prepared for each somatostatin molarity evaluated, and five without somatostatin served as controls. Incubations were terminated by medium aspiration, followed by extensive cell washing with $2.5 \%$ acetic acid in distilled water. Chondrocytes were treated with $0.5 \%$ Triton X-100 $(100 \mu \mathrm{L} /$ well, $10 \mathrm{~min}$ ) and collected in a multiple-cell harvester on glass fiber filters. The filters were dried and counted in $10 \mathrm{~mL}$ Unisolve in a beta-counter for $10 \mathrm{~min}$. Results were expressed as cpm of radioactivity/tissue culture well.

Statistical analysis. The results are expressed as the mean \pm SEM. The differences between groups were analyzed by the Mann-Whitney U test.

\section{RESULTS}

Figure 1 shows the effect of somatostatin on ${ }^{3} \mathrm{H}$-thymidine DNA incorporation by cultured chondrocytes from a 34-wk-old human fetus after $96 \mathrm{~h}$ of incubation in a serum-free medium. For the last $48 \mathrm{~h}$, cells were incubated in the presence or absence of somatostatin. A significant $(p<0.02)$ inhibitory effect versus controls was observed for 1 and $10 \mathrm{nM}$. However, no significant 


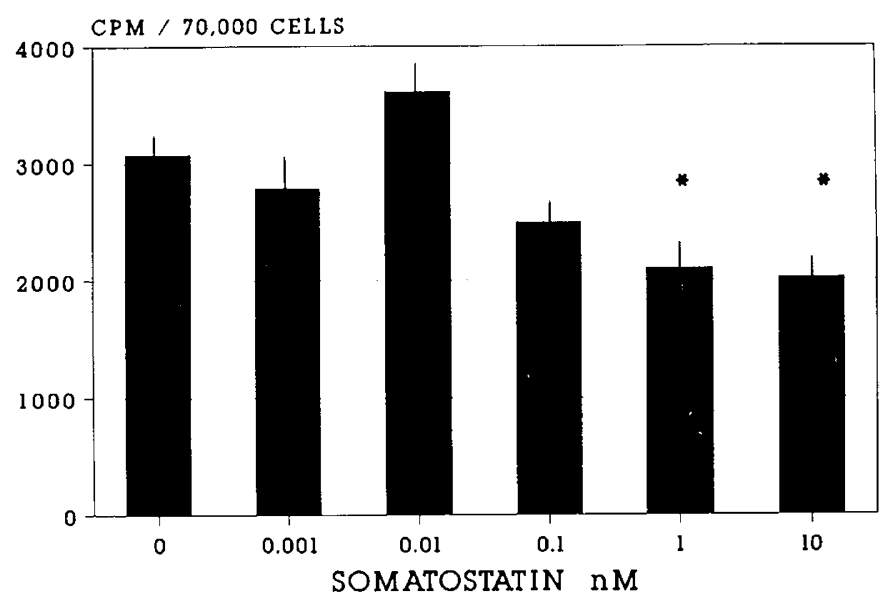

Fig. 1. Somatostatin effects on ${ }^{3} \mathrm{H}$-thymidine DNA incorporation by cultured epiphyseal chondrocytes from a 34 -wk-old human fetus. Cells were incubated in a serum-free medium for up to $96 \mathrm{~h}$, the last $48 \mathrm{~h}$ in the presence or absence of somatostatin. ${ }^{*}, p<0.02 v s$ controls, $n=5$.



Fig. 2. Somatostatin effects on ${ }^{3} \mathrm{H}$-thymidine DNA incorporation by cultured chondrocytes from human fetuses $12-40 \mathrm{wk}$ old. Cells were incubated in a serum-free medium for up to $96 \mathrm{~h}$, the last $48 \mathrm{~h}$ in the presence or absence of somatostatin. Each value is the mean of five points. Results are expressed as a relative value vs controls of the same experiment. Controls $=100 .^{*}, p<0.02$ vs controls in the same experiment.

effects versus controls were observed for the other molarities evaluated. Similar results were observed when somatostatin 0.001 to $10 \mathrm{nM}$ effects were evaluated in cultured chondrocytes from human fetuses $16,24,26,34,36$, and $40 \mathrm{wk}$ old (data not shown). In addition, somatostatin 100 and $1000 \mathrm{nM}$ significantly $(p<0.02)$ inhibited DNA- ${ }^{3} \mathrm{H}$-thymidine incorporation by cultured chondrocytes from a 12-wk-old human fetus (data not shown).

Figure 2 summarizes the effects of somatostatin on ${ }^{3} \mathrm{H}$-thymidine DNA incorporation by cultured chondrocytes from human fetuses 12-40 wk old. Cells were incubated for $96 \mathrm{~h}$ in a serum-free medium, the last $48 \mathrm{~h}$ in the presence or absence of somatostatin. Results are expressed as a relative value versus controls, with controls being 100. A significant $(p<0.02$ or more versus the absolute value of controls in the same experiment) inhibitory effect was observed for somatostatin $1 \mathrm{nM}$ to $10 \mu \mathrm{M}$ for all gestational ages evaluated (12-40 wk).

\section{DISCUSSION}

Cultured human fetal epiphyseal chondrocytes incubated in a serum-free medium for periods of time up to $96 \mathrm{~h}$ are able to incorporate ${ }^{3} \mathrm{H}$-thymidine into DNA, and this suggests that these cells may synthesize growth factors, which, acting in a paracrine/ autocrine way, might regulate their own growth and differentiation as has also been described in other chondrocyte culture models (13-15). Our earlier unpublished results concur with this fact, inasmuch as we found that cultured human fetal epiphyseal chondrocytes synthesize IGF-I, IGF-II, and epidermal growth factor and that these growth factors significantly stimulate ${ }^{3} \mathrm{H}$ thymidine-DNA incorporation by these cultured cells.

Somatostatin at molarity concentrations similar to those at which it exerts biologic effects on its target cells (16-20) significantly inhibits DNA synthesis in cultured human fetal epiphyseal chondrocytes. These results are in agreement with the mechanism of action of somatostatin, which inhibits secretory (21) and proliferative (16-20) processes in a large variety of cells.

The mechanism of action of somatostatin inhibiting DNA synthesis in cultured human fetal epiphyseal chondrocytes remains to be elucidated. Recently, it has been published that, in cultured FRTL5 thyroid follicular cells of the rat, somatostatin inhibits the stimulatory effect of IFG-I on DNA synthesis (20). From these data, it may be speculated that in our human fetal chondrocyte culture model somatostatin might inhibit the stimulatory effect of one or more of the several growth factors synthesized by these cells (see above), but at present this is speculative and remains to be proved.

Long-term somatostatin analog treatment of children with excessive adult height prediction has shown a significant reduction in growth velocity during therapy, and this has been attributed to the somatostatin-induced decrease in growth hormone secretion $(22,23)$. However, according to several experimental data that show that somatostatin binds to and exerts biologic effects on neonatal rat calvaria (17) and neonatal rat long bones (24), that somatostatin inhibits proliferation and differentiation of cartilage and bone cells (25), and that the administration of somatostatin to mice inhibits longitudinal bone growth (26), it has been suggested that the somatostatin effect on the reduction of growth velocity in these children might in part be due to a direct effect of somatostatin on skeletal growth (27). Epiphyseal cartilage plays a central role in skeletal growth (1), and our results clearly show that somatostatin inhibits DNA synthesis in cultured human fetal epiphyseal chondrocytes and support the idea that these cells might be a target for somatostatin action. Our results also suggest that somatostatin might regulate skeletal growth, not only by regulating growth hormone secretion but also by acting locally on epiphyseal chondrocyte metabolism. However, the significance of the latter in physiologic skeletal growth regulation remains to be clarified.

In conclusion, our data show that cultured human fetal epiphyseal chondrocytes are able to elicit a biologic response to somatostatin, as occurs in somatostatin target cells. Our results also suggest that somatostatin could regulate human skeletal growth not only through growth hormone secretion regulation but also by exerting a local effect on epiphyseal cartilage regulating chondrocyte metabolism.

Acknowledgments. The authors are grateful to P. Andaluz for excellent technical assistance and to C. O'Hara for useful manuscript corrections.

\section{REFERENCES}

1. Sissons H 1971 The growth of bone In: Bourne GH (ed) The Biochemistry and Physiology of Bone. Academic Press, New York, pp 145-180

2. Krulich L, Dhariwal APS, McCann SM 1968 Stimulatory and inhibitory effects of purified hypothalamic extracts on growth hormone release from rat pituitary in vitro. Endocrinology 83.783-790

3. Brazeau P, Vale W, Ling N, Butcher M, Rivier J, Guillemin R 1973 Hypothalamic polypeptide that inhibits the secretion of immunoreactive pituitary growth hormone. Science 179:77-79

4. Reichlin S 1983 Somatostatin (part 1). N Engl J Med 309:1495-1501

5. Reichlin S 1983 Somatostatin (part 2). N Engl J Med 309:1556-1563 
6. Aubert ML, Grumbach MM, Kaplan S 1977 The ontogenesis of human fetal hormones. IV. Somatostatin, luteinizing hormone releasing factor, and thyrotropin releasing factor in hypothalamus and cerebral cortex of human fetuses 12-22 weeks of age. J Clin Endocrinol Metab 44:1130-1141

7. Kumasaka T, Hishi N, Yapi Y, Kido Y, Saito M, Okayasu I Shimizu K, Hatakeyama S, Sawano S, Kobuku K 1979 Demonstration of immunoreactive somatostatin-like substance in villi and decidua in early pregnancy. Am J Obstet Gynecol 134:39-41

8. Watkins WB, Yen SSC 1980 Somatostatin in cytotrophoblast of the immature human placenta: localization by immunoperoxidase cytochemistry. J Clin Endocrinol Metab 50:969-97!

9. Audi L, Carrascosa A, Ballabriga A 1984 Androgen metabolism by human fetal epiphyseal cartilage and its chondrocytes in primary culture. $\mathrm{J}$ Clin Endocrinol Metab 58:819-825

10. Carrascosa A, Audi L, Ferrández MA, Ballabriga 1990 Biological effects of androgens and identification of specific dihydrotestosterone-binding sites in cultured human fetal epiphyseal chondrocytes. J Clin Endocrinol Metab 70: $134-140$

11. Carrascosa A, Ferrández MA, Audi L, Ballabriga A 1992 Triiodothyronine effects and identification of specific nuclear triiodothyronine binding sites in cultured human fetal epiphyseal chondrocytes. J Clin Endocrinol Metab 75:140-144

12. Carrascosa A, Audi L, Ballabriga A 1985 Morphologic and metabolic development of human fetal epiphyseal chondrocytes in primary culture. Pediatr Res 19:720-727

13. Shen V, Rifas L, Kohler G, Peck WA 1985 Fetal rat chondrocytes sequentially elaborate separate growth- and differentiation-promoting peptides during their development in vitro. Endocrinology 116:920-925

14. Schlechter C, Russell SM, Spencer EM, Nicoll CS 1986 Evidence suggesting that the direct growth-promoting effect of growth hormone on cartilage in vivo is mediated by local production of somatomedin. Proc Natl Acad Sci USA 83:7932-7934

15. Burch WM, Weir S, Van Wyk JJ 1986 Embryonic chick cartilage produces its own somatostatin-like peptide to stimulate cartilage growth in vitro. Endocrinology 119:1370-1376
16. Chou $\mathrm{CH}$, Ho L, Ting LP, Hu CH, Su TS, Chang WCH, Suen $\mathrm{CH}$, Huang MY, Chang CG 1987 Selective suppression of insulin-induced proliferation of cultured human hepatoma cells by somatostatin. J Clin Invest 79: $175-178$

17. Silve C, Licberherr M, Garabedian M, Guillozo H, Gross B, Thil CL, Balsan S 1981 Somatostatin and vitamin D3 metabolites in rat calvarium: in vitro evidence for physiological interaction. Endocrinology 109:1454-1462

18. Setyono-Han B, Henkelman MS, Foekens JA, Klijn GM 1987 Direct inhibitory effects of somatostatin (analogues) on the growth of human breast cancer cells. Cancer Res 47:1566-1570

19. Taylor JE, Bogden AE, Moreau JP, Coy DH 1988 In vitro and in vivo inhibition of human small cell lung carcinoma (NCI-H69) growth by a somatostatin analogue. Biochem Biophys Res Commun 153:81-86

20. Tsuzaki S, Moses A 1990 Somatostatin inhibits deoxyribonucleic acid synthesis induced by both thyrotropin and insulin-like growth factor-I in FRTL5 cells. Endocrinology 126:3131-3138

21. Pittenger GL, Vinik AI, Heldsinger AA, Seino S 1985 Regulation and actions of gastrointestinal somatostatin. In: Patel YC, Tannenbaum GS (eds) Somatostatin. Plenum Press, New York, pp 447-462

22. Hindmarsh PC, Pringle PJ, di Silvio L, Brook CGD 1990 A preliminary report on the role of somatostatin analogue (SMS 291-995) in the management of children with tall stature. Clin Endocrinol 32:83-91

23. Tauber MT, Tauber JP, Vigoni E, Harris AG, Rochiccholi P 1990 Effect of the long-acting somatostatin analogue SMS 201-995 on growth rate and reduction of predicted adult height in ten tall adolescents. Acta Paediat Scand 79:176-181

24. Bruns C, Dietl MM, Palacios JM, Pless J 1990 Identification and characterization of somatostatin receptors in neonatal rat bones. Biochem J 265:39-44

25. Weiss RE, Reddi AH, Nimni ME 1991 Somatostatin can locally inhibit proliferation and differentiation of cartilage and bone precursor cells. Calcif Tissue Int 33:425-430

26. Marie PJ, Hott M, Durand D 1988 Somatostatin infusion inhibits stimulatory effect of testosterone on endosteal bone formation in the mouse. Metabolism $37: 429-435$

27. Lamberts SWJ 1991 Somatostatin analogs: their role in the treatment of growth hormone hypersecretion and excessive growth. Growth Regulation 1:3-10 